\title{
Cyanobacteria Occurrence and Nitrogen Fixation Rates in the Seagrass Meadows of the East Coast of Zanzibar: Comparisons of Sites With and Without Seaweed Farms
}

\author{
Thomas J. Lyimo*1 and Mariam I. Hamisi ${ }^{1,2}$ \\ ${ }^{1}$ Molecular Biology and Biotechnology Department, University of Dar-es-Salaam, P.O. Box 35179, Dar es \\ Salaam, Tanzania; ${ }^{2}$ Botany Department, Stockholm University, S-106 91, Stockholm, Sweden
}

Keywords: Cyanobacteria, Nitrogen Fixation, Seagrass, Seaweed Farming

\begin{abstract}
The occurrence and biological nitrogen fixation rates of epiphytic and benthic diazotrophs were studied in seagrass meadows at sites with seaweed farms and at control site without seaweed farms from two locations, Chwaka Bay and Jambiani, along the east coast of Zanzibar. Ten species of cyanobacteria were encountered and Lyngbya majuscula and Microcoleus sp. were dominant in Chwaka Bay and Jambiani respectively. Cyanobacterial occurrence was significantly higher in seagrass meadows without seaweed farms $(\mathrm{P}<0.02)$, but there was no significant difference $(\mathrm{P}>0.05)$ in biomass (chlorophyll $a$ ). Biomass averaged $2.96 \pm 0.73$ and $3.10 \pm 1.24 \mu \mathrm{g} \mathrm{Chl} a \mathrm{~cm}^{-2}$ in seaweed farms and 3.46 $\pm 1.72 \mu \mathrm{g} \mathrm{Chl} a \mathrm{~cm}^{-2}$ at Chwaka Bay and $3.14 \pm 1.31 \mu \mathrm{g} \mathrm{Chl} a \mathrm{~cm}^{-2}$ at Jambiani in transects without seaweed farms. Nitrogenase activity showed no significant differences between sites with and without seaweed farms, $(\mathrm{P}=0.66 \mathrm{Chwaka}$ and 0.75 at Jambiani). Fixation rates in sites without seaweed farms averaged 35.8 \pm 39.9 (Chwaka Bay) and $13.1 \pm 12.7$ (Jambiani) $\mu \mathrm{mol}$ of $\mathrm{C}_{2} \mathrm{H}_{4}$ produced $/ \mathrm{m}^{2} / \mathrm{hr}$, while with seaweed farms averaged 22.6 \pm 22.5 and $12.8 \pm 14.9 \mu \mathrm{mol} \mathrm{C}_{2} \mathrm{H}_{4}$ produced $/ \mathrm{m}^{2} / \mathrm{hr}$ at the same sites. There were no significant differences in nutrient levels between locations, sites with and without seaweed farms, or between tidal levels except for nitrate, which was significantly higher $(\mathrm{P}=0.01)$ at Jambiani than at Chwaka Bay. It was concluded that diazotrophs contribute a significant amount of exogenous nitrogen to the seagrass ecosystem, but no significant differences could be found between sites with or without seaweed farms.
\end{abstract}

\section{INTRODUCTION}

Seagrass meadows support a high biodiversity and contribute substantially to the productivity of coastal waters (Ochieng \& Erftemeijer, 2003). Their production sometimes exceeds that of seaweeds and corals (Sorokin, 1993). Seagrasses are hosts to many epiphytic organisms such as microalgae, macroalgae, bacteria and a number of invertebrate species (Uku \& Björk, 2001). The high diversity and density of flora and fauna in seagrass beds create remarkably high rates of primary and secondary productivity. In addition, the epiphyte communities associated with seagrass ecosystems may contribute significantly to nutrient cycling through nitrogen fixation, denitrification and sulphate reduction processes (Harris, 1999; Hansen et al., 2000).

Biological nitrogen fixation is limited to some free-living and symbiotic prokaryotic organisms, collectively known as diazotrophs. In the marine environment, this important process substantially contributes to 'new production' i.e., primary production associated with newly available nitrogen. Epiphytic and epibenthic microorganisms associated with seagrass beds play an important role in the nitrogen fixation process 
(Lugomela, 2002; Hamisi et al., 2004). Lyngbya, Oscillatoria, Calothrix and Nodularia are some of the cyanobacterial genera that demonstrate nitrogenase activity and are found in seagrass beds (Bergman et al., 1997; Lugomela, 2002; Hamisi et al., 2004). Heterotrophic bacteria that fix nitrogen are also found in association with seagrasses where they are supported by the dissolved organic carbon released from the seagrass roots and rhizomes. Various studies showed that the rate of nitrogen fixation is much higher in and around seagrass bed than in non-vegetated areas (Patriquin \& Knowles, 1972; Welsh, et al., 2000; Hamisi, 2005). For example, Hamisi (2005) noted a significantly higher nitrogen fixation rates $\left(6.7 \mu \mathrm{mol}\right.$ of $\left.\mathrm{N}-\mathrm{fixed} / \mathrm{m}^{2} / \mathrm{hr}\right)$ in the sediment within seagrass meadows compared to bare sediments $\left(0.036 \mu \mathrm{mol}\right.$ of $\mathrm{N}$-fixed $\left./ \mathrm{m}^{2} / \mathrm{hr}\right)$. This also coincided with a significantly higher cyanobacteria biomass in the seagrass sediments.

Diazotrophs and their nitrogen fixation rates can be affected by a number of factors such as light availability, dissolved inorganic nutrients, temperature, diurnal and seasonal variations. Erftemeijer and Middelburg (1995) and Hemminga and Duarte (2000) reported that nitrogen fixation rates are generally higher in tropical and subtropical seagrass meadows than in temperate seagrass meadows due to the higher temperature and lower nutrient concentrations.

Factors that threaten seagrass beds may also affect the diazotrophs and their nitrogen fixation rates. Seagrass ecosystems have been threatened by anthropogenic activities such as sewage disposal, mariculture, destructive fishing activities, construction works, sediment alteration (siltation) and dredging (Short \& Wyllie-Echeverria, 1996). Along the east coast of Zanzibar, Tanzania, extensive seaweed farming of the red algae Eucheuma sp. has occurred since the late 1980's. About 7,000 metric tonnes dry weight of seaweed is harvested annually (Eklund and Petterson, 1992). The growth rate of Eucheuma sp. was recorded up to $11 \%$ per day in early days of seaweed farming at Paje, but dropped to $4-7 \%$ in a few years (Eklund \& Petterson, 1992; Mtolera, 2003). Since the harvesting of Eucheuma sp. is high, the removal of nitrogen from the system may be considered to be substantial, hence input of new nitrogen into the system becomes very important for sustainable ecosystem production. The epiphytic and benthic diazotrophs, the abundance of which are higher in areas with seagrass than in bare sediments (Hamisi, 2005), expected to be one among the sources of readily available nitrogen to the seaweeds. This study assesses cyanobacterial diversity, abundance and nitrogen fixation rates in seagrasses meadows with and without seaweed farms.

\section{MATERIALS AND METHODS}

\section{Study site and Sampling}

The study was conducted at two locations, Chwaka Bay and Jambiani along the east coast of Zanzibar, located at $6^{\circ} 10^{\prime} \mathrm{S}, 39^{\circ} 26^{\prime} \mathrm{E}$ and at $6^{\circ} 6^{\prime} \mathrm{S}, 39^{\circ} 32^{\prime} \mathrm{E}$, respectively. Seagrasses at these locations are found in intertidal and subtidal areas between the beach and the coral reefs. Seaweed farms are restricted to the lower intertidal areas in both locations, though substrates are different. Chwaka Bay is an intertidal lagoon dominated by tidal flats and channels, its mid littoral zone characterized by soft sandy substrates, while the lower zone is formed from calcareous algal sediments. At Jambiani there exists a wide intertidal lagoon with the mid littoral zone consists of fine sand substratum with the lower zone characterized by coarse sand substrate and reef structures.

The sampling design involved two transects at each location, one passing through seaweed farms and the other in an area without seaweed farm, both extending perpendicular to the shoreline. Along each transect two sampling sites were selected, parallel to the shoreline at mid-intertidal zone (100 $150 \mathrm{~m}$ ) from the shoreline and in the lower intertidal zone (only exposed during spring tide). Thus, a total of eight sampling sites were included, abbreviated as: CAM, CAL, CBM, CBL (Chwaka) and JAM, JAL, JBM JBL (Jambiani); and corresponding to the labeling of sites as follows: Chwaka Bay (C); Jambiani (J); without seaweed farms (A); through seaweed farms (B); mid-intertidal zone (M) and low-intertidal zone (L). Sampling was conducted four times, in May and November 2003 and in March and June 2004. 


\section{Physical and chemical parameters}

Triplicate measurements of temperature and salinity of the seawater were made at each sampling site during every sampling period, using a mercury thermometer and a hand-held refractometer (Salt Refractometer 300011 SPER SCIENTIFIC China).

Nutrient concentration (nitrate, nitrite and phosphate) was measured from the seawater and sediment pore waters. Seawater samples were collected, filtered through $\mathrm{GF} / \mathrm{C}$ micro fibre filter paper $(0.45 \mu \mathrm{m})$ and placed in the plastic bottles. The pore water samples were extracted from sediment core samples collected up to $5 \mathrm{~cm}$ deep using a core of $6 \mathrm{~cm}$ in diameter. The extraction was done in the laboratory using a suction pump equipped with filter papers $(0.45 \mu \mathrm{m}-\mathrm{GF} / \mathrm{C})$. The filtered samples briefly stored at $20{ }^{\circ} \mathrm{C}$ and then analysed for nutrients concentrations according to Parsons et al. (1989).

\section{Epiphytic and epibenthic cyanobacteria: diversity and abundance}

Triplicate samples of seagrass plants (Thalassia hemprichii) together with their root systems, surrounding sediment and any encountered algal mats were collected in each sampling site and placed in plastic bottles. In the laboratory, the samples were analyzed as described by Hamisi $e t$ al. (2004). Duplicate samples of seagrass plants and sediment were collected from all sites for microalgae biomass (chlorophyll $a$ ) analysis. Epiphytes were removed by carefully scraping leaf surfaces of whole seagrass plants in $10 \mathrm{ml}$ filtered seawater, which was then filtered through microfibre filter paper $(0.45 \mu \mathrm{m})$. The scraped leaves were dried and weighed. Sediment samples for chlorophyll $a$ analysis were taken with a corer of $2.5 \mathrm{~cm}$ diameter to about $0.5 \mathrm{~cm}$ depth and filtered and drained as described above and analyzed for chlorophyll a (Parsons et al., 1989).

\section{Nitrogen fixation rates}

The rate of nitrogen fixation was measured in triplicate samples of seagrass plants and sediments by the acetylene reduction assay method (Capone,
1993). Whole seagrass plants were collected using a shovel, while sediment samples were collected with a corer of a $6.7 \mathrm{~cm}$ diameter to a depth of $0.5 \mathrm{~cm}$. One third of the volume of the incubation bottles was filled with samples and approximately $10 \%$ of the headspace was replaced with acetylene. No acetylene was added to the control samples. The samples were then incubated in situ for about 2 hours. After incubation, $5 \mathrm{ml}$ of gas samples were withdrawn and placed in $5 \mathrm{ml}$ vacutainers (Becton-Dickinson) and stored in the dark at room temperature until analysis with a Gas Chromatograph (GC-HP 5890 II) equipped with Flame Ionization Detector and a column packed with porapack $\mathrm{N}$ (80/100-mesh size). Nitrogen gas was used as a carrier gas at a flow rate of $35 \mathrm{ml} /$ min. Oven, detection and injection port temperature were set at 80,200 and $170{ }^{\circ} \mathrm{C}$, respectively. For the expression of the amount of nitrogen fixed per gram, the biomass of the seagrass tissue in the assay bottle was measured on an analytical balance after drying the sample in an oven at $70{ }^{\circ} \mathrm{C}$ to a constant weight.

\section{Statistical analysis}

Statistical tests were carried out as described by Zar (1999) using Graph Pad Instant $t_{\mathrm{m}}$ 1990-1993 software for t-test. In addition, two-way analysis of variance (ANOVA) in STATISTICA package (6.0) was used to analyse some variables. Prior to the analysis, the data were subjected to normality and homogeneity of variance tests. Where assumptions for parametric test were not met, data were transformed $\left(\log _{10}\right)$. P-values less than 0.05 were considered to represent significant differences.

\section{RESULTS}

\section{Physical and chemical parameters}

The temperature and salinity at the study sites ranged from $28.9-35.0{ }^{\circ} \mathrm{C}$ and $31.5-35.0 \%$, respectively (Fig. 1a). The concentrations of phosphate, nitrite and nitrate in the seawater ranged from 0.09-0.28 $\mu \mathrm{mol} \mathrm{PO}_{4}-\mathrm{P} \mathrm{l}^{-1}, 0.15-0.32 \mu \mathrm{mol} \mathrm{NO}-\mathrm{N} \mathrm{l}^{-1}$ and 1.32-2.07 $\mu \mathrm{mol} \mathrm{NO}_{3}-\mathrm{N} \mathrm{l}^{-1}$, respectively. In sediment pore waters, the nutrient concentrations ranged from 
0.22-0.89 $\mu \mathrm{mol} \mathrm{PO}_{4}-\mathrm{P} \mathrm{l}^{-1}, 0.2-0.57 \mu \mathrm{mol} \mathrm{NO}_{2}-\mathrm{N}$

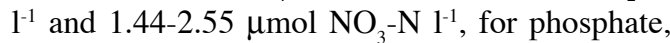
nitrite and nitrate (Fig. 1b-d), respectively. Tukey comparison test showed that pore water nutrient concentrations were not significantly higher than those in seawaters, and there were no significant differences in nutrient levels between sites with and without seaweed farms, mid and low intertidal zones or Chwaka and Jambiani, except for nitrate which was significant higher $(\mathrm{P}=0.01, \mathrm{~F}=10.2)$ at Jambiani than at Chwaka Bay.

\section{Epiphytic cyanobacteria: diversity and biomass}

Ten species of cyanobacteria were encountered in mats on the sediments or as epiphytes on seagrasses. The most common species were Lyngbya majuscula and Microcoleus sp. in Chwaka and Jambiani respectively. Other species included Oscillatoria limosa, O. princeps, O. subuliformis, Phormidium sp., Lyngbya aestuarii, Merismopedia sp., Nodularia sp. and Anabaena sp. (Table 1).
Generally, cyanobacteria were found to occur in both seagrass meadows with and without seaweed farms. However, in transects passing through seaweed farms there were fewer mats attached on poles, sediments, and seagrass, while transects away from seaweed farms had more cyanobacterial mats on sediments and seagrasses. No cyanobacterial mats were observed attached to the farmed seaweeds.

Out of the ten species of cyanobacteria encountered, nine were found in seagrass meadows without seaweed farms, while five species were found in transects passing through seaweed farms. Wilcoxon's paired sample test showed a significantly higher frequency of cyanobacteria occurrence in seagrass meadows without seaweed farms than in sites with seaweed farms $(\mathrm{P}<0.02)$. Furthermore, seven cyanobacteria species were encountered in Jambiani and eight in Chwaka and there were no significant differences in the frequency of occurrence between the two locations $(\mathrm{P}=0.81)$.

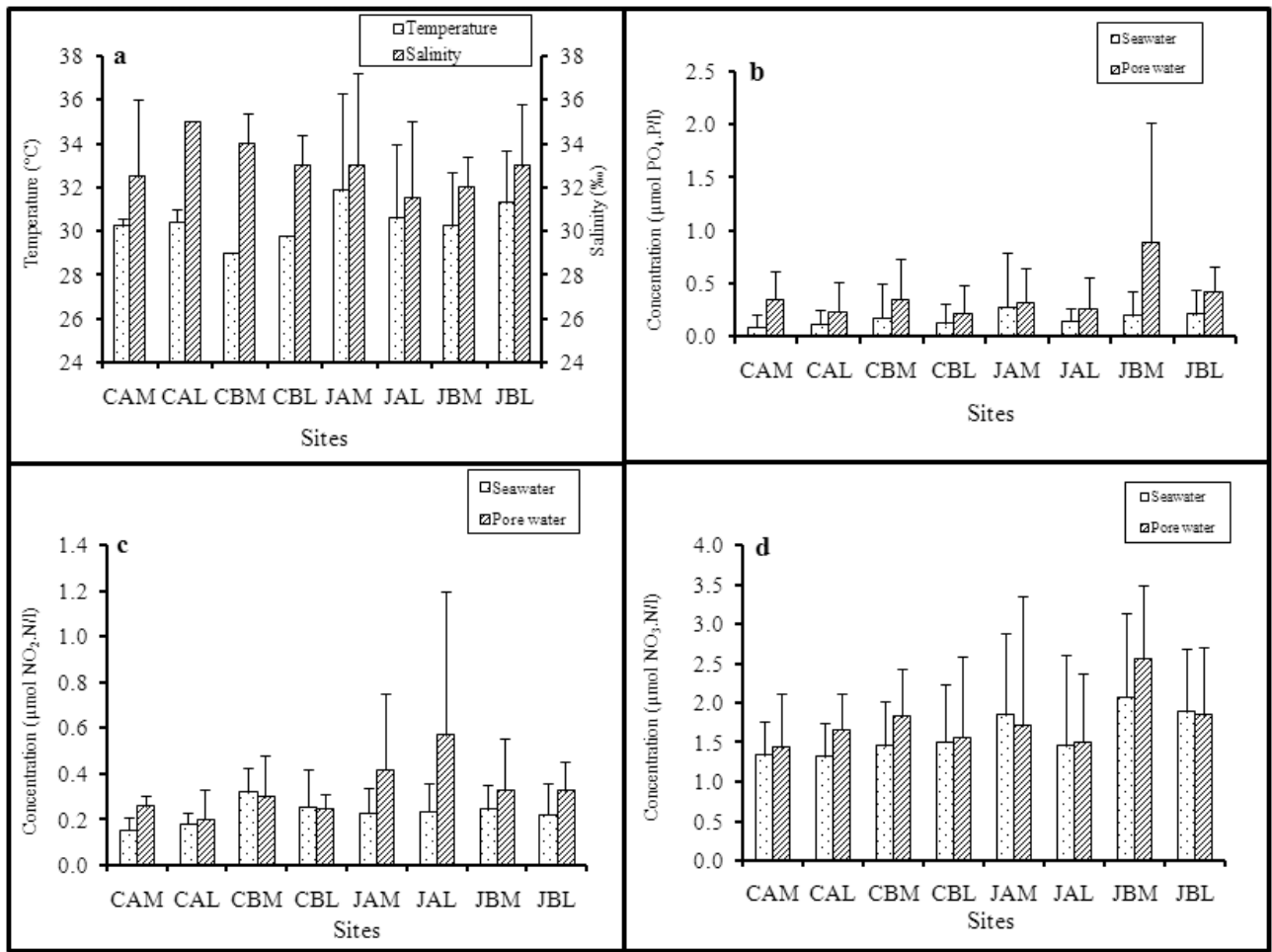

Fig. 1. Physical and chemical parameters at the study sites (for abbreviations, see text): (a) Salinity and temperature (b) phosphate, (c) Nitrite, (d) Nitrate 
Table 1. Cyanobacteria encountered at Chwaka Bay and Jambiani. (JA = Jambiani without seaweed; JB = Jambiani with seaweed; $\mathrm{CA}=$ Chwaka without seaweed; $\mathrm{CB}=$ Chwaka with seaweed; $\mathrm{Se}=$ sediments; $\mathrm{Ep}=$ epiphyte on seagrass; $F N h=$ filamentous non-heterocystous cyanobacteria, $U$ = unicellular cyanobacteria; $F h=$ filamentous heterocystous cyanobacteria; $\mathbf{n m}=$ not measured; * bundle size; + Present; and, - not found)

\begin{tabular}{lllllllll}
\hline Cyanobacteria species & JA & JB & CA & CB & Width $(\boldsymbol{\mu m})$ & Length $(\boldsymbol{\mu m})$ & Habitat & Type \\
\hline Lyngbya majuscula & + & - & + & - & 42 & 2.5 & Ep\&Se & FNh \\
Lyngbya aestuarii & - & + & - & - & 17.4 & 1.9 & Poles, Se & FNh \\
Oscillatoria limosa & + & + & + & + & 20 & 3.2 & Ep\&Se & FNh \\
Oscillatoria princeps & + & + & + & + & 16.7 & 3 & Ep\&Se & FNh \\
Oscillatoria subuliformis & - & - & + & + & $5-7.2$ & $6.3-7.1$ & Ep\&Se & FNh \\
Microcoleus sp. & + & + & + & + & $15-45^{*}$ & $5.4-6.3$ & Ep\&Se & FNh \\
Phormidium sp, & + & - & + & - & 3.3 & 11 & Se & FNh \\
Merismopedia sp. & - & - & + & - & $\mathrm{nm}$ & $\mathrm{nm}$ & $\mathrm{Se}$ & $\mathrm{U}$ \\
Anabaena sp. & - & - & + & - & $\mathrm{nm}$ & $\mathrm{nm}$ & $\mathrm{Se}$ & $\mathrm{Fh}$ \\
Nodularia sp. & + & - & - & - & $\mathrm{nm}$ & $\mathrm{nm}$ & $\mathrm{Se}$ & Fh \\
\hline
\end{tabular}

The mean biomass of epiphytic microalgae, measured as chlorophyll $a(\mathrm{Chl} a)$ concentration, ranged from $1.2 \pm 1.1-1.4 \pm 1.8 \mu \mathrm{g} \mathrm{Chl} a \mathrm{~g}^{-1}$ and $1.2 \pm 1.8-5.4 \pm 4.1 \mu \mathrm{g} \mathrm{Chl} a \mathrm{~g}^{-1}$ in meadows with and without seaweed farms respectively. Chlorophyll concentrations in the range of $1.4 \pm 1.0-2.7 \pm 1.3$ $\mu \mathrm{g} \mathrm{Chl} a \mathrm{~cm}^{-2}$ and $1.2 \pm 1.0-1.7 \pm 0.5 \mu \mathrm{g} \mathrm{Chl} a \mathrm{~cm}^{-2}$ were measured in seagrass meadow sediments, with and without seaweed farms respectively.

The total microalgae biomass (sediment and epiphytic) measured as chlorophyll $a(\mathrm{Chl} a)$ concentration averaged $2.96 \pm 0.73$ and $3.10 \pm 1.24$ $\mu \mathrm{g} \mathrm{Chl} a \mathrm{~cm}^{-2}$ in sites with seaweed farms and $3.46 \pm 1.72$ and $3.14 \pm 1.31 \mu \mathrm{g} \mathrm{Chl} a \mathrm{~cm}^{-2}$ in sites without seaweed farms at Chwaka Bay and Jambiani, respectively. The analysis showed that there was no significant difference in the total microalgae biomass (sediments + epiphytic) $(\mathrm{P}=0.54)$ between seagrass meadows with and without seaweed farms at both locations (Fig. 2a).

The epiphytic chlorophyll $a$ concentration was significantly higher in the mid intertidal zone than the low intertidal zone in the sites without seaweed farms at Chwaka ( $\mathrm{P}=0.02$, Fig. 2a), but not at Jambiani. However, there were no significant differences in epiphytic $\mathrm{Chl} a$ concentration between the mid and low intertidal zones in sites with seaweed farms at both location, with P-values of 0.37 and 0.46 , at Chwaka and Jambiani respectively (see Fig. 2a). Levels of microalgae biomass in the sediment did not show any clear variance between sampling occasions or sites (Fig. 2b), and, there was no significant difference in total chlorophyll $a$ concentrations between the two locations (also see Fig. 2c).

\section{Nitrogen fixation rates}

The nitrogen fixation rates by epiphytic microalgae (diazotrophs) associated with seagrasses found in the transect without seaweed farms averaged to $8.2 \pm 4.4$ and $27.4 \pm 5.9 \mathrm{nmol} \mathrm{C}_{2} \mathrm{H}_{4}$ produced/ $\mathrm{hr} / \mathrm{g} \mathrm{dw}$ of seagrass for Chwaka mid and low sites, respectively, while in Jambiani the average value measured were $14.4 \pm 7.4$ and $4.7 \pm 3.9 \mathrm{nmol}$ $\mathrm{C}_{2} \mathrm{H}_{4}$ produced/hr/g dw of seagrass in mid and low sites, respectively (Fig 3a). In the transects passing through the seaweed farms, the average values were $6.3 \pm 2.4$ and $24.1 \pm 8.9 \mathrm{nmol} \mathrm{C}_{2} \mathrm{H}_{4}$ produced $/ \mathrm{hr} / \mathrm{g} \mathrm{dw}$ of seagrass in Chwaka mid and low sites, respectively, while in Jambiani the values were $10.8 \pm 6.4$ and $5.1 \pm 3.3$ in mid and low sites, respectively (Fig. 3a). The nitrogen fixation rates by the epiphytes attached to seagrass were not significantly different (Two-way ANOVA) between sites with and without seaweed farms at both locations, $\mathrm{P}=0.66, \mathrm{~F}=0.19$ and $\mathrm{P}=0.75, \mathrm{~F}=0.10$ at Chwaka and Jambiani respectively. However, the rates were significantly higher in the low intertidal zone than in the mid intertidal zone in Chwaka at both sites $(\mathrm{P}<0.05)$, while there were no significant differences between mid and low intertidal zone in Jambiani at both sites. The interaction of the two factors (zonation and seaweed farming) showed significant differences, with a greater significance in the low intertidal zone site without seaweed 


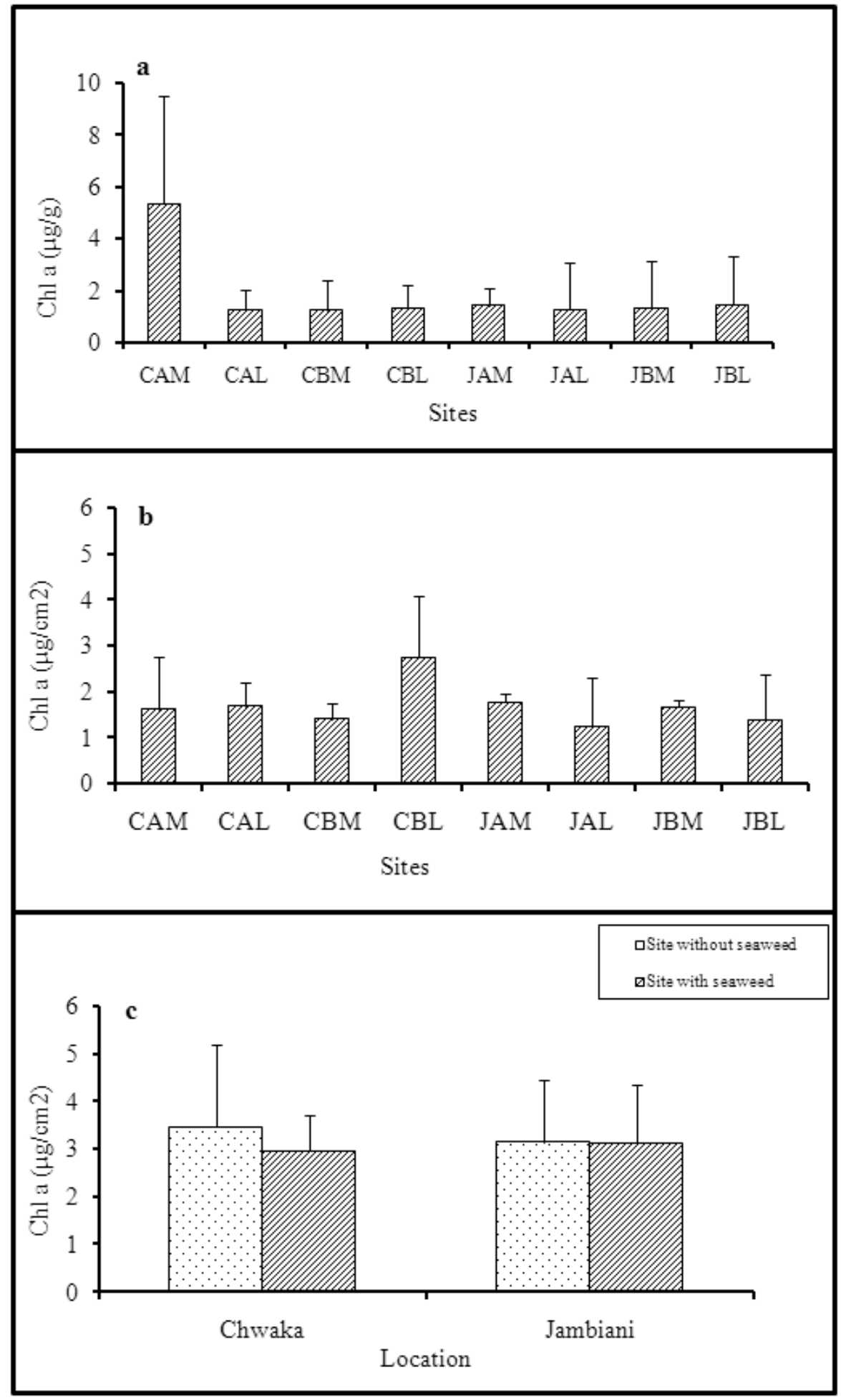

Fig. 2. Chlorophyll a concentration as a measure of microalgae biomass: (a) Chlorophyll a concentration of epiphytic microalgae attached to the seagrass (b) Chlorophyll a concentration of benthic microalgae in the sediments (c) Total chlorophyll a concentration (epiphytic + benthic microalgae) 
farms at Chwaka $(\mathrm{P}=0.02)$, but no significant difference at Jambiani. In addition, there was no significant difference in the amount of nitrogen fixed by epiphytes attached to seagrasses between Chwaka and Jambiani at both sites with and without seaweed farms.

Averages of the amount of nitrogen fixation rates in the sediments along transects with and without seaweed farms in both mid and low sites at both location shown in figure $3 \mathrm{~b}$. Results revealed no significant differences (two-way ANOVA) in the rates of nitrogen fixed in the sediments between sites with and without seaweed farms at both location $(\mathrm{P}=0.75$ at Chwaka and $\mathrm{P}=0.06$ at Jambiani). There were also no significant differences between the mid and low intertidal zones at both stations $(\mathrm{P}=0.31$ and 0.74 at Chwaka and Jambiani, respectively), and the interaction of the two factors did not show significant differences at both sites. Moreover, there were no significant differences in the amount of nitrogen fixed in the sediment between Chwaka and Jambiani in areas with and without seaweed farms.

Total nitrogen fixation rates by epiphytic and benthic diazotrophs in seagrass meadows at sites with seaweed farms averaged $35.8 \pm 39.9$ and $13.1 \pm 12.7 \mu \mathrm{mol}$ of $\mathrm{C}_{2} \mathrm{H}_{4}$ produced $/ \mathrm{m}^{2} / \mathrm{hr}$, in Chwaka and Jambiani respectively, while in the sites without seaweed farms these values reached $22.6 \pm 22.5$ and $12.8 \pm 14.9 \mu \mathrm{mol}$ of $\mathrm{C}_{2} \mathrm{H}_{4}$ produced/ $\mathrm{m}^{2} / \mathrm{hr}$, for Chwaka and Jambiani, respectively (Fig. $3 \mathrm{c})$. There were no significant differences in the total amount of nitrogen fixed between the sites with and without seaweed farms and between mid and low intertidal zones at both stations. Likewise, there was no significant difference in the amount of total nitrogen fixed between Chwaka and Jambiani at both sites with $(\mathrm{P}=0.41)$ and without $(\mathrm{P}=0.15)$ seaweed farms. In addition, there was no significant correlation between the rates of nitrogen fixed with nutrients and Chl. $a$ concentration.

\section{DISCUSSION}

The various physical and chemical factors measured during this study in both seaweed and non-seaweed farming sites were comparable with previously reported values for the coastal waters of Tanzania (Francis et al., 2001; Hamisi et al., 2004). The lack of significant differences in nutrient levels between transects, with and without seaweed farms, and mid and low intertidal zones may indicate that seaweed farming and zonation did not have a significant influence on the levels of dissolved inorganic nutrients. However, the significantly higher nitrate levels in Jambiani compared to Chwaka Bay indicate that Jambiani may suffer from a higher degree of anthropogenic pollution.

The presence of cyanobacterial mats in seagrass meadows is related to the physical stability, protective cover and lack of the excreted toxic material by the seagrasses (Whitton \& Potts, 1982, Hamisi et al., 2004). The lack of cyanobacteria on the farmed seaweeds could be dues to the texture of the seaweed surface and to the excretion by the seaweeds of toxic substances, such as hydrogen peroxide and halogenated toxins, which prevent colonization and deter herbivory (Mtolera et al., 1995).

The higher frequency of occurrence of cyanobacteria in seagrass meadows without seaweed farms, than in those with seaweed farms, could be explained by human disturbances related to farming activities, such as frequent movements in and out of the farms, dragging of seaweed bags during harvesting and transportation to the beach, which may cause destruction of the seagrasses and other biota dependent on them (Semesi, 2002; Eklöf et al., 2005; Lyimo et al., 2006). Light may also be limiting at the farm sites, as seaweeds are known to be better competitors for light than the benthic phototrophic organisms (Duarte, 1995) and this could be exacerbated by ropes and ties associates with seaweed farms. Although there was higher occurrence of cyanobacteria in sites without seaweed farms, than in sites with seaweed farms, there was no significant difference in microalgae biomass (chlorophyll a) between sites. This could be due to the contribution of other microalgae to the total biomass as cyanobacteria tend to be outcompeted by other faster growing microalgae such as diatoms (Uku \& Björk, 2001; Hamisi et al., 2004). The trend of decreasing microalgal biomass seawards in transects passing through seagrass beds without seaweed farms as observed at Chwaka, could be due to the zonation and specificity of the cyanobacteria colonization on different seagrass species, or to the increase in wind and currents 


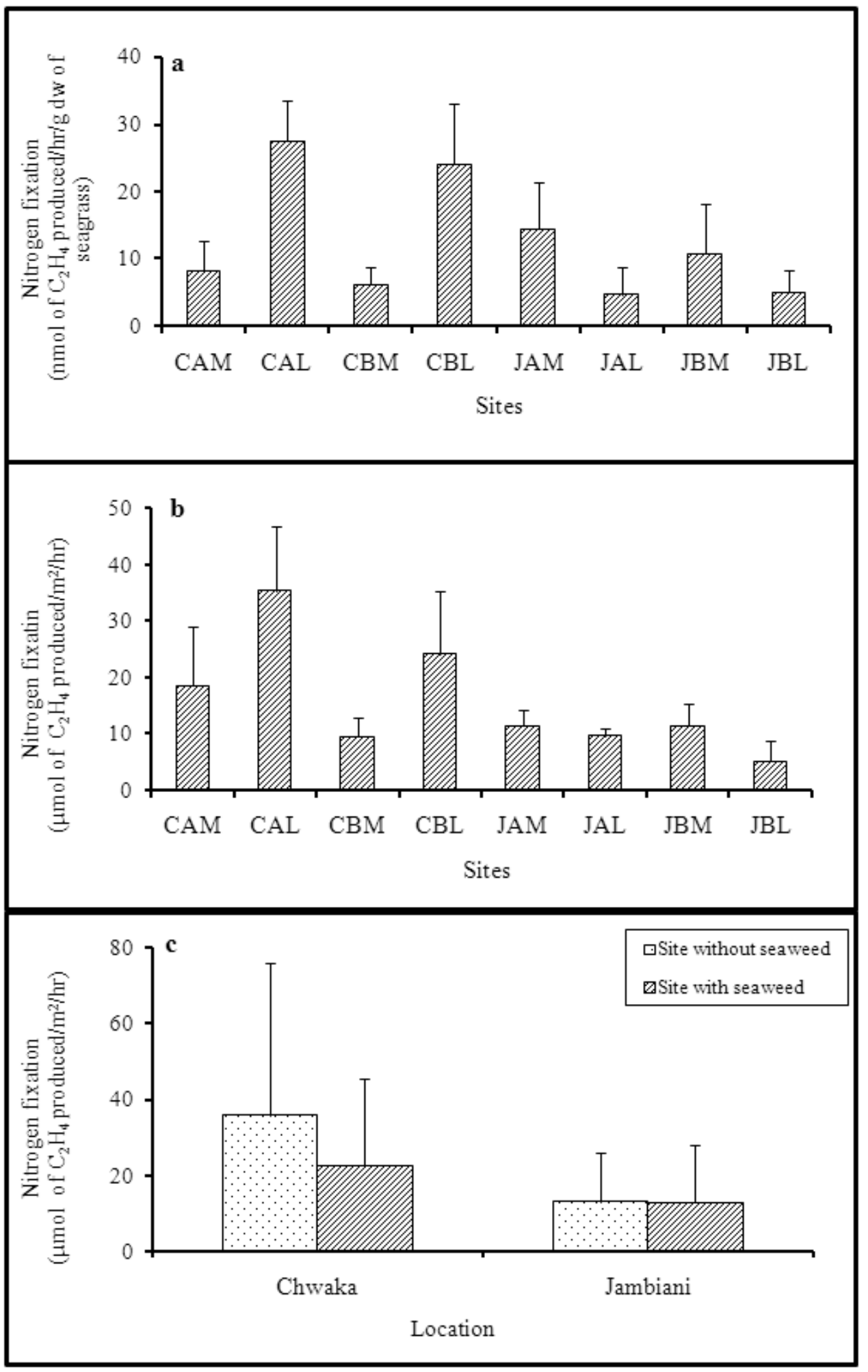

Fig. 3. The rate of ethylene production as a measure of nitrogen fixation rates: (a) Rates by epiphytic microalgae attached to seagrasses (b) Rates by diazotrophs in the sediments (c) Total fixation rates (epiphytic + benthic microalgae) 
that disturb cyanobacteria settlement. Lack of significant difference at Jambiani could be due to the different in nutrient levels (nitrate) that might have influenced microalgal distribution (Hamisi et al., 2004; Uku et al., 2007). Rapid expansion of the seaweed farms in Jambiani was observed, which may result in greater disturbance. Disturbance from the seaweed farming activities may result in the loss of the microalgae from the seagrass beds and could be the reason for the insignificant differences between mid and low intertidal zone in transects with seaweed farms.

Cyanobacteria contribute significantly to the introduction of "new" combined nitrogen in marine ecosystems (e.g. Lugomela, 2002; Kyaruzi et al., 2003; Sjőling et al., 2005; Hamisi, 2005; Lyimo and Lugomela, 2006). The nitrogen fixation rates recorded at Chwaka Bay and Jambiani fall in the range recorded in similar environments within the region and elsewhere. Lugomela and Bergman (2002) reported ethylene production rates to range of 1.30-16.8 $\mathrm{nmol} \mathrm{C}_{2} \mathrm{H}_{4} \mathrm{~cm}^{-2} \mathrm{hr}^{-1}$ in mangrove sediments of Zanzibar. Paerl et al. (1996) reported nitrogenase activity ranging from 0.0 to $9.0 \mathrm{C}_{2} \mathrm{H}_{4}$ $\mathrm{cm}^{-2} \mathrm{hr}^{-1}$ during the winter and in the summer, respectively, in the intertidal mudflats of North Carolina. Stal et al. (1984) reported ethylene production rates ranging from $0.6-87.2 \mathrm{C}_{2} \mathrm{H}_{4} \mathrm{~cm}^{-2}$ $\mathrm{hr}^{-1}$ in the intertidal flats of Mellum Island in the North Sea.

The results show no significant differences in nitrogen fixation rates between sites with and without seaweed farms, regardless of the difference in cyanobacteria composition between these sites. It may be that cyanobacteria in seagrass on the seaweed farms are maximizing the nitrogen fixation rates to compete with the growing seaweed, which are known to have higher affinity for nutrients than cyanobacteria. Other diazotrophs may also make a contribution to the total nitrogen fixed and this, combined with low cyanobacterial abundance, could also affect nitrogen fixation levels.

Earlier studies in Zanzibar have shown decreases in seagrass cover and biomass as a result of the seaweed cultivation (Semesi, 2002; Mtolera, 2003; Eklöf et al., 2005). It may be that the decrease seagrass cover and biomass is linked to a decrease in the number and activity of their associated species. However, higher nitrate levels reported in Jambiani could be the reason for the lack of significant difference in nitrogen fixation rates due to feed back inhibition as the increasing inorganic nutrients, particularly combined nitrogen may lower or inhibit nitrogenase activity (Welsh $e t$ al., 1996).

Seagrasses provide suitable habitats for diazotrophs and hence contribute to sustaining the productivity of the seaweeds by adding new readily available nitrogen to the system. Consequently, disturbances that alter the seagrass biomass and associated diazotrophs abundance may affect nitrogen fixation rates and in turn result in lower seaweed productivity. Growth rates of farmed Eucheuma dropped from $11 \%$ per day in the early days of seaweed farming to around 4-7\% in a few years later (Eklund \& Petterson, 1992). Mtolera (2003) reported lower (20-75\%) growth rates of two genera of farmed red algae (Eucheuma and Kappaphycus) in Paje (an area with low seagrass cover) than Uroa (an area with high seagrass cover), perhaps due to lower nutrient availability. The conclusion from the present study is that diazotrophs contribute a significant amount of exogenous nitrogen to the seagrass ecosystem. The seaweed farming activities could not have a significant alteration on the physical chemical parameters of the seagrass ecosystems, but could influence biodiversity and functional alteration due to mechanical or physical disturbance. Impacts from physical disturbance and mechanical removal of seagrasses in seaweed farming areas was apparent, but did not seem to significantly affect nitrogen fixation rates. In addition, it should be noted that, the higher standard deviations in this study could be attributed to patchiness in abundance and varying composition of the diazotrophic organisms. Lack of significant differences, however, may be due to the fact that the effects have not yet reached threshold levels. Therefore, periodic studies to monitor this important ecosystem are recommended.

Acknowledgement-This study was done with financial support from the Western Indian Ocean Marine Science Association (WIOMSA) through a Marine Science for the Management (MASMA) grant. We are thankful to the Institute of Marine Science (IMS) Zanzibar and the Botany Department, University of Dar-es-Salaam for field and laboratory 
logistics. We would also like to thank Mr. Thomas Buluda, Ms. Dotto Salum and Mr. Juma Nene and all members of the MASMA Seagrass project team for their cooperation in the field. We also thank the anonymous reviewers for their valuable comments on the manuscript.

\section{REFERENCES}

Bergman, B., Gallon, J.R., Rai, A.N. \& Stal, L.J. (1997) $\mathrm{N}_{2}$ fixation by non- heterocystous cyanobacteria. FEMS Microbiol. Rev. 19: 139-185.

Capone, D.G. (1993) Determination of nitrogenase activity in aquatic samples using the acetylene reduction procedure. In: Kemp, P.F, F.B. Sherr, B.E. Sherr, \& J.J. Cole, (eds) Handbook of Methods in Aquatic Microbial Ecology. p. 621-631.

Duarte, C.M. (1995) Submerged aquatic vegetation in relation to different nutrient regime. Ophelia 41: $87-112$.

Erftemeijer, P.L.A \& Middelburg, J.J. (1995) Mass balance constraints on nutrient cycling in tropical seagrass beds. Aquat. Bot. 50: 21-36.

Eklöf, J.S., de la Torre Castro, M., Adelsköld, L., Jiddawi, N.S. \& Kautsky, N. (2005) Differences in macrofaunal and seagrass assemblages in seagrass beds with and without seaweed farms. Estuar. Coast. Shelf Sci. 63: 385-396.

Eklund, S. \& Petterson, P. (1992) Mwani is Money. The Development of Seaweed farming on Zanzibar and its socio-economic effects in the village of Paje. Report from a Minor Field Study (Working Paper 24, Development Studies Unit, Department of Social Anthropology, Stockholm University, $67 \mathrm{pp}$.

Francis, J., Mahongo, S. \& Semesi, A. (2001) The coastal Environment. Eastern Africa Atlas of Coastal Resources Tanzania. UNEP Kenya. p. 9-47.

Hamisi, M.I. (2005) Nitrogen fixation in Seagrass Ecosystems along Dar es Salaam coastal Waters, Tanzania. M.Sc Thesis, University of Dar es Salaam. 103 pp.

Hamisi, M.I., Lyimo, T.J. \& Muruke, M.H.S. (2004) Cyanobacterial occurrence and diversity in seagrass meadows in Coastal Tanzania. WIO J. Mar. Sci. 3: 113-122.

Hansen, J.W., Udy, J.W., Perry, C.J., Dennison, W.C. \& Lomstein, B.A. (2000) Effects of seagrass Zostera capricorni on sediment microbial processes. Mar. Ecol. Prog. Ser. 199: 83-96.

Harris, G.P. (1999) Comparison of the biogeochemistry of lakes and estuaries: ecosystem processes, function groups, hysteresis effects and interaction between macro- and microbiology. Marine and Freshwater Research. 50: 791-811.

Hemminga, M.A \& Duarte, C.M. (2000) Seagrass Ecology. Cambridge University Press. United Kingdom. 295 pp.

Kyaruzi, J.J., Kyewalyanga, M.S. \& Muruke, M.H.S. (2003) Cyanobacteria composition and impacts of seasonality on their in situ nitrogen fixation rate in a mangrove ecosystems adjacent to Zanzibar town. WIO J. Mar. Sci. 2: 35-44.

Lugomela, C. (2002) Cyanobacterial diversity and productivity in coastal areas of Zanzibar, Tanzania. Ph.D. Thesis, Stockholm University. 41 pp.

Lugomela, C. \& Bergman, B. (2002). Biological $\mathrm{N}_{2}$ fixation on mangrove pneumatophores: preliminary observations and perspectives. Ambio. 31: 612-613.

Lyimo, T.J. \& Lugomela, C. (2006) Nitrogenase Activity in Intertidal Sediment along the Tanzanian Coast, western Indian Ocean. WIO J. Mar. Sci. 5 (2): 133-140.

Lyimo, T.J., Mvungi E.F., Lugomela, C. \& Björk, M. (2006) Seagrass biomass and productivity in seaweed and non-seaweed farming areas in the East Coast of Zanzibar, Tanzania. WIO J. Mar. Sci. 5 (2): 141-152.

Mtolera, M.S.P. (2003) Effects of seagrass Cover and Mineral Content on Kappaphycus and Eucheuma Productivity in Zanzibar. WIO J. Mar. Sci. 2: 163-170.

Mtolera, M.S.P., Collen, J., Pedersen, M. \& Semesi,A.K. (1995) Destructive Hydrogen peroxide production in Eucheuma denticulatum (Rhodophyta) during stress caused by elevated $\mathrm{pH}$ and light intensities and competition with other species. Eur. J. Phycol. 30: $297-298$.

Ochieng, C.A \& Erftemeijer, P.L.A. (2003) The Seagrasses of Kenya and Tanzania. In: Short \& Green (eds). World Atlas of Seagrasses. Prepared by the UNEP-WCMC. University of California Press, Barkeley, USA. p. 82-92.

Paerl, H.W., Fitzpatrick, M. \& Bebout, B.M. (1996) Seasonal $\mathrm{N}_{2}$ Fixation dynamics in a marine microbial mat: Potential roles of cyanobacteria and microheterotrophs. Limnol. Oceanogr. 41(3): 416-427.

Parsons, R.T., Maita, Y. \& Lalli, C.M. (1989) A Manual of Chemical and Biological Methods for Seawater Analysis. Pergamon Press, Oxford. 173 pp.

Patriquin, D \& Knowles, R. (1972) Nitrogen fixation in the rhizosphere of marine angiosperms. Mar. Biol. 16: 49-58.

Semesi, I.S. (2002) Ecological and Socio-Economic Impacts of Farmed Eucheuma Seaweeds in Zanzibar, Tanzania. M.Sc. Thesis, Agricultural 
University of Norway. $77 \mathrm{pp}$.

Short, F.T \& Wyllie-Echeverria, S. (1996) Natural and human-induced disturbances of seagrasses. Environ. Conserv 23: 17-27.

Sjöling, S., Mohammed, S.M., Lyimo, T.J., \& Kyaruzi, J.J. (2005) Benthic bacteria diversity and nutrient processes in Mangroves: Impacts of deforestation. Estuar. Coast. Shelf Sci. 63: 397-406.

Sorokin, Y.I. (1993) Composition of reef plant associations. In: Sorokin Y.I. (ed.) Coral Reef Ecology. Spring- Verlag, Berlin Heidelberg New York, p. 144-150.

Stal, L.J., S. Grossberger \& Krumbein, W.E. (1984) Nitrogen fixation associated with the cyanobacterial mat of a marine laminated microbial ecosystem. Mar. Biol. 82: 217-224

Uku, J \& Björk, M. (2001) The distribution of epiphytic algae on three Kenyan seagrass species. S. Afr. J. Bot. 67: 475-482.

Uku, J., Björk, M., Bergman, B. \& Díez, B. (2007) Characterization and Comparison of Prokaryotic
Epiphytes Associated with three E. African Seagrasses. J. Phycol. 43:768-779.

Welsh, D.T., Wellsbury, P., Bourgues, S., de Wit, R \& Herbert, R.A. (1996) Relationship between porewater organic carbon content, sulphate reduction and nitrogen fixation (acetylene reduction) in the rhizosphere of Zostera noltii. Hydrobiologia 329: 175-18.

Welsh, D.T., Bartoli, M., Nizzoli, D., Castaldelli, G., Riou, S.A. \& Viaroli, P. (2000) Denitrification, nitrogen fixation, community primary productivity and inorganic $-\mathrm{N}$ and Oxygen fluxes in an intertidal Zostera noltii meadow. Mar.Ecol. Prog. Ser. 208: 65-77.

Whitton, B.A \& Potts, M. (1982) Marine Littoral. In: Carr, N.G and B.A. Whitton, (eds). The Biology of Cyanobacteria. Blackwell Science Publication, Oxford. p. 515-552.

Zar, J.H. (1999) Biostatistical Analysis. $4^{\text {th }}$ ed. Prentice Hall, Inc, Englewood cliffs, New Jersey. 662 pp. 
